\title{
Entre livros e telas - a narrativa para crianças e jovens: saberes sensíveis e olhares críticos
}

\author{
Maria ZiLDA DA CunHa \\ Universidade de São Paulo
}

\begin{abstract}
RESUMO: NOSSO PROPÓSITO NESTE ARTIGO É TECER BREVES REFLEXÕES SOBRE A LITERATURA PARA CRIANÇAS E JOVENS COMO FENÔMENO LITERÁRIO, PORTANTO, CONSIDERANDO SUA COMPLEXIDADE E INTRÍNSECA RELAÇÃO COM A CULTURA, COM A HISTÓRIA E A EVOLUÇÃO SOCIAL. PERSPECTIVA QUE IMPLICA VISUALIZÁ-LA NESTE MUNDO REPRESENTADO POR NOVAS TECNOLOGIAS COMUNICACIONAIS E MEDIADO POR NOVAS FORMAS DE PRODUÇÃO DE LINGUAGEM.
\end{abstract}

ABSTRACT: OUR GOAL IS TO COMPOSE BRIEF REFLECTIONS ABOUT LITERATURE TO CHILDREN AND YOUNG PEOPLE, AS A LITERARY PHENOMENON, THEREFORE, IN ITS COMPLEXITY AND INTRINSIC RELATION WITH THE CULTURE, WITH THE HISTORY AND WITH THE SOCIAL EVOLUTION. SUCH PERSPECTIVE IMPLIES VISUALIZING IT IN THIS WORLD REPRESENTED BY NEW COMMUNICATIONAL TECHNOLOGIES AND MEDIATED BY NEW WAYS OF LANGUAGE PRODUCTION.

PALAVRAS-CHAVE: REVOLUÇÃO TECNOLÓGICA - LEITURA - LITERATURA INFANTIL - LINGUAGEM

KEY-WORDS: TECNOLOGICAL REVOLUTION - READING - INFANTILE LITERATURE LANGUAGE 


\section{Nota introdutória}

"Navegar é preciso, viver não é preciso."

(Fernando Pessoa)

Em tempos de poderosas tecnologias comunicacionais, reverberam as palavras do poeta como se cumprissem o seu destino. Em uma era hipercomplexa, a sociedade humana conecta-se por redes interplanetárias de telefonia e de sensores óticos, estabelecendo formas de socialização ciberculturais - modo pelo qual navegam a criança e o jovem contemporâneos - dentro de um espaço informacional, em um ambiente de signos híbridos no qual gráficos, figuras, palavras, textos, sons e vídeos misturam-se na construção de uma metamídia complexa.

Essas são as marcas desta nossa era, cujas perspectivas parecem nublar a consciência de que os séculos anteriores viram o livro tomar sua forma, assistiram ao surgimento e expansão das línguas modernas e das literaturas que exploraram suas possibilidades expressivas, cognoscitivas e imaginativas.

Não é por caso que nos interrogamos a respeito da literatura - arte da palavra - a respeito do livro - suporte tão privilegiado da palavra escrita - a respeito do ensino da literatura e do texto destinado a criança e ao jovem contemporâneo.

Sem qualquer pretensão de futuróloga, tenho me dedicado a pesquisas sobre a literatura para crianças e jovens e as novas tecnologias. Isto se deve menos à sedução pelos avanços tecnológicos e mais à minha confiança na criança - na esteira de W. Benjamim, para quem ela recolhe o lixo da história e dá novas ordenações; e à minha confiança no futuro da literatura que consiste em acreditar que há algo que só a literatura como arte pode nos dar. Diria, seguindo Charles S. Peirce (1839-1914), que ela tem potencialidade para levar adiante o projeto humano do homem, mesmo que esse ser, como nos parece, esteja mergulhado em tempestade diluviana da ordem social e econômica.

Parte do projeto objetiva dimensionar a produção artística contemporânea para jovens e crianças, verificando em que medida as experiências, que emergem na relação com novos ambientes midiáticos, se tornam capazes de articular a pluralidade em enlaces complexos e comunitários que não se submetam à padronização unilateral que, por enquanto, é ameaça. Uma inves- 
tigação, nesse sentido requer olhar a literatura para crianças e jovens como fenômeno literário, e desse modo, em sua complexidade e totalidade, em sua intrínseca e inseparável relação com a cultura, a história e a evolução social. Sem perder de vista tais aspectos, orientamos nossa pesquisa pela via do diálogo como forma de intercambiar conhecimentos, textos e culturas e, ao mesmo tempo, redescobri-los.

\section{Lendo o problema da leitura}

As discussões sobre leitura, literatura e linguagem, hoje já revelam alguns redimensionamentos: reconhece-se que o nascimento de um novo meio não leva à morte, nem desintegra aquele que o precedeu. A tendência, como assinalou Santaella (1996), é a criação de sistemas integrais, interdependentes, de modo que um meio se alimenta do outro ao mesmo tempo em que o retroalimenta. Posicionamento que coincide com o de John Cage, quando diz: "não é necessário renunciar ao passado ao entrar no porvir. Ao mudar as coisas, não é necessário perdê-las".

Com efeito, convivem hoje diferentes gerações de meios e linguagens, de caráter artesanal, cujo regime de recepção é de culto, as produções caráter técnico, reprodutível, cujo regime de recepção é de exposição, e as realizadas com tratamento digital, sem referentes externos, cujas formas de recepção podem assumir valor de recriação.

Outro aspecto importante está no fato de que, apesar da relevante invasão das imagens potencializada pelo desenvolvimento das mídias áudio visuais, ser um usuário competente da linguagem escrita é fundamental em nossa sociedade. Além de uma via de acesso e integração no tríplice universo do trabalho, da cultura simbólica e das relações sociais, sem dúvida, o domínio da linguagem verbal, em especial em sua modalidade escrita, constitui um instrumento valioso para o desvendamento das conexões que montam a teia de exploração do homem pelo homem. Importa lembrar, entretanto, que a compreensão da realidade abarca um processo lógico, que ultrapassa os limites lingüísticos e envolve uma atividade semiótica no sentido lato, onde mais sistemas de signos se complementam reciprocamente.

O funcionamento da cultura é inseparável da comunicação e um papel cabe às tecnologias de informação e comunicação. Nestes termos, importa 
colocar sob mira formas de produção de cultura instauradas pelo processo midiático, posto que os processos comunicativos, exercidos pelas mídias, funcionam como atividades culturais criando seus sistemas modelares secundários (padrões hegemônicos, crenças, sistemas de leis). Geram códigos específicos, produzem efeitos perceptivos peculiares, formas de recepção próprias, legitimam comportamentos sociais característicos. Portanto, é necessária a compreensão da linguagem para além das fronteiras do verbal no sentido de compreender o funcionamento dos discursos assim produzidos afinando um olhar critico a esse respeito.

A propósito de tal discussão impõe-se ainda o reconhecimento de que, com a introdução da escrita nos meios eletrônicos, emergem novas formas de leitura. Em diferentes momentos históricos, cada sociedade, em função das tecnologias de que dispõe, faz emergir tipos específicos de leitores. À guisa de exemplo, vale citar os tipos estudados por Santaella, o leitor contemplativo, o movente e o imersivo. O primeiro - próprio do iluminismo - para quem não conta o tempo, tem diante de si textos duráveis (livros) e que podem ser revisitados a todo e qualquer momento. "Um leitor que contempla e medita. Entre os sentidos, a visão reina soberana, complementada pelo sentido interior da imaginação." (SANTAELLA, 2007). O segundo, fruto da revolução industrial, do desenvolvimento do capitalismo, recebe grande apelo de informações simultâneas e é desafiado à decifração de textos híbridos. Já o terceiro está emergindo com os atuais suportes eletrônicos e estruturas híbridas e alineares do texto escrito, é o leitor que navega pela rede virtual, seleciona informações em redes textuais com links múltiplos.

Conforme já asseverou Chartier (1999), ler sobre uma tela não é ler um códex, a materialidade do livro foi substituída pela imaterialidade ${ }^{1}$ de textos sem lugar específico; às relações de contiguidade estabelecidas no objeto impresso opõe-se a livre composição de fragmentos infinitamente manipuláveis - são textos móveis que se dobram e se desdobram à vontade diante do leitor. Com a desmaterialização do texto eletrônico, vamos ter um suporte dinâmico que distribui textos on line, as mensagens não se confundem mais com seus

1 Imaterialidade significa uma outra materialidade, pois existe sob uma forma codificada realizada pela organização de estados eletromagnéticos dos sinais de 0 e 1 . Comporta uma matriz virtual e potencial em memória que pode ser atual, visualizável por meio de transcodificadores. As mensagens imateriais não se confundem com seus suportes, elas circulam através de múltiplos dispositivos. 
suportes, circulam por dispositivos múltiplos, alterando o fluxo linear para realizações em arquiteturas hipertextuais.

Contudo, o livro em nossa sociedade conserva um lugar bastante importante. As novas formas de linguagem não o anulam, mas se enredam nele, aliás, o lêem. Lêem-no mediante outros signos. Diversos códigos migram para livro, da mesma forma como códigos do livro migram para outros suportes, e, com esse trânsito, os textos vão assumindo características de estrutura hipertextual; o que vai requerer um programa de acesso via leitura com características de um mapa de navegação multidirecional e interativo do hipertexto do computador para explorar os limites e possibilidades desse hiperlivro, feito de links múltiplos, que vão traçando vias permutacionais pelas quais é possível navegar.

\section{Nas sendas do literário, um prazer para a infância}

Estamos vivendo uma revolução da informação, da comunicação e do conhecimento sem precedentes, em especial, se atentarmos para a velocidade das transformações históricas. Numa zona fronteiriça da formação do homem deste milênio, boa parte da literatura para crianças e jovens apresenta novos modos construtivos, pela inserção de novas tecnologias na produção, recepção e consumo, pela hibridização de linguagens verbais, visuais e sonoras, bem como pela inserção de motivações de caráter cultural mais amplo como a consciência de uma complexidade cada vez maior do pensamento e da vida, pela descoberta do comportamento instável e caótico do universo. ${ }^{2}$

Ao fim e ao cabo, numa rede urdida, a literatura plasma mutações do mundo das linguagens, a intercomunicação das culturas e as dinâmicas sociais. São modificações que evidentemente alteram as relações (de autoria, obra, recepção) no interior do sistema literário, transformam as relações que se estabelecem entre literatura e fatores externos a ela, modificam as formas de mediação de leituras. ${ }^{3}$

2 O que nem sempre garante a qualidade e adequação das novas produções dedicadas à juventude.

3 A leitura da literatura, a formação do leitor literário passa por mediações organizadas por adultos. 
Os métodos de análise e ação, os modos de trabalhar e educar, fortemente desafiados, buscam rearticulações constantes. Para Edgar Morin, este milênio, exige do educador a reinvenção de formas, e de formas capazes de dar conta do pensamento complexo desta era. Além do mais, não podemos perder de vista que está sendo alargado o âmbito do que se espera de um leitor infantil.

Com efeito, a propósito dos aspectos elencados, merecem atenção ainda: a forma como a arte da palavra se consubstancia nas inter-relações que assume com as demais artes, com outras formas de representação e comunicação, incluindo as operações de linguagem que estão a traduzir os objetos literários para outros suportes ou mídias.

Para Júlio Plaza (1998: 98), “a operação de linguagem de um meio para outro implica em consciência tradutora capaz de perscrutar não apenas os meandros da natureza do novo suporte, seu potencial e limites, mas a partir disso, dar o salto qualitativo, isto é, passar de mera reprodução para a produção". Em outras palavras, "traduzir com invenção pressupõe reinventar a forma, isto é, aumentar a informação estética." (Ibid.).

A dimensão estética ${ }^{4}$ da literatura para crianças e jovens (até muito pouco tempo desconsiderada), seja em textos apenas tecidos pelo verbo, seja em diálogos de imagem e palavra, oferece à criança possibilidade de fruição prazerosa - uma espécie de estado monádico, integrador, unificador, pela qualidade de sentimento que lhe é peculiar.

A arte, nas suas diversas formas de linguagem manifesta, reveste-se da marca da Estética. Desse modo, seus objetos tornam-se capazes de provocar a experiência da admirabilidade - normalmente, denominada prazer estético, e que pode ser definida como um prazer provocado pelo sentimento e pelo intelecto numa interação indissociável (cf. Peirce). Algo como uma simpatia intelectual. Essa atitude diante da obra envolve a porosidade sensória do deleite, o esforço interpretativo implicado na percepção (entre a observação atenta e distraída), a imaginação (base de toda atividade criadora do cérebro humano) e a promessa do assentimento intelectivo (CUNHA, 2002).

Atitude, de modo algum passiva ou abobada, posto que, na leitura de um texto artístico, se há algo que atrai, se há um entretenimento, há também uma

4 Não podemos esquecer que a questão da estética envolve uma discussão muito mais ampla, a literatura como arte é um objeto privilegiado de materialização do estético. 
razão criativa que atua junto com o sentimento. Para a criança, mesmo de forma não consciente, o texto entra em diálogo sempre com um concreto histórico, uma vez que precisa acionar conhecimentos prévios e esquemas interpretativos. Portanto, se qualidade de sentimento, percepção, imaginação e intelecto são convocados para a decifração dos enigmas do texto ficcional, processa-se uma leitura no engendrar de sensações, imagens, diagramas de compreensão, hipóteses, experimentações e raciocínio, de forma a articular um complexo sígnico que consubstancia o texto literário em sua função social, ideológica e estética.

A literatura, como arte, por excelência, encarna qualidades de sentimento e "formas de sabedoria, de um tipo que fala à sensibilidade, ao mesmo tempo em que convida a razão a se integrar ludicamente ao sentir" (SANTAELLA, 1996: 151). Daí, se hábitos de ação e de pensamento podem ser alterados por meio de argumentos logicamente montados ou por bom senso, os hábitos de sentimento apenas se modificam na presença de situações que impulsionem sua regeneração, necessitam estar diante de uma corporeidade sensível. Assim, o ideal estético é nutrido pelo cultivo de hábitos de sentimento. A adoção desse ideal promove o aparecimento de um empenho ético e a necessidade da lógica para o controle crítico do pensamento para atingi-lo.

Seria, desse modo, a literatura uma instância privilegiada na formação da criança deste nosso tempo.

\section{Literatura, matrizes de linguagem e pensamento, processos de pro- dução de linguagem e vida social}

A arte é um fazer, transforma a matéria oferecida pela natureza num movimento que arranca o ser do não ser. Arte é conhecimento, envolve sensorialidade, percepção, representação e estilização. Envolve imaginação construtiva, conhecimento de estruturas; percepção artística (BOSI, 2004). Para Alfredo Bosi, a arte também supõe trabalho, jogo, liberdade e técnica. Técnica é um saber fazer, refere-se a um conjunto de habilidades e procedimentos que se aprendem, que se criam, se desenvolvem. Até a Revolução Industrial, por exemplo, as técnicas de produção artística eram artesanais, hoje, vinculam-se a equipamentos tecnológicos, são máquinas de linguagem (FLÜSSER, 1985). 
A literatura, como toda manifestação de arte, é produzida por meios que são históricos. Assim, em seus primórdios era indissociável da voz, da música; com a invenção da escrita, legitima-se como arte das letras e com o advento dos meios técnicos de impressão, ganha visualidade e passa a explorar os tipos gráficos para a criação de sentidos; convoca para seu nicho de criação a imagem e, hoje, com as novas tecnologias hipermidiáticas, encontra terreno fértil para outras experimentações.

Santaella, (2001) que faz considerações a respeito de seis grandes eras civilizatórias que marcam as culturas humanas e nas quais as artes encontram-se inexoravelmente imbricadas: a oral, a escrita, a da comunicação impressa, a da comunicação de massa, a da comunicação midiática, a digital, demonstra que, embora seqüenciais, todas elas sobrepõem-se, hoje, compondo uma malha cultural complexa e densa. Essa autora organiza um pouco da complexidade histórica que nos enreda nesta era, realizando um mapeamento que culmina em uma teoria das matrizes de linguagem e pensamento.

A pesquisadora, considerando a pluralidade de linguagens que o homem foi capaz de desenvolver ao longo de sua história, afirma que há três, apenas três matrizes: a sonora, a visual e a verbal, das quais as demais são hibridismos. Sua teoria liga indissoluvelmente faculdades cognitivas aos sentidos, sistemas de signos e linguagens manifestas.

Para a uma abordagem preliminar do vasto universo da literatura infantil (CUNHA, 2002), tomamos por base esses pressupostos e elegemos três vetores de formas de produção das matrizes de linguagens humanas, no interior dos quais buscamos tangenciar condições de produção, a configuração e da dinâmica da obra e das relações com o público receptor, levando em conta aspectos sociais que envolvem a atividade artística em diferentes momentos históricos. (CANDIDO, 1985).

No primeiro, estariam as linguagens: verbal, visual e sonora, em seu modo de produção artesanal; na relação muito íntima entre produtor e receptor; para a construção dos sentidos concorrem as manipulações performáticas do corpo e da voz. São manifestações às quais se ligam a transmissão imediata, a participação do público ouvinte intensificando e interferindo, nos próprios elementos da elaboração criativa - estão em jogo os aspectos sociais e culturais de uma vida coletiva, em função de elementos que interessam a todos, a sua visão de mundo e da sociedade. (CANDIDO, 1985). 
No segundo, teríamos os processos de produção de linguagens mediados pela tecnologia. Processos capazes da propagação e difusão da voz no espaço e tempo; técnicas óticas de formação das imagens, processos híbridos de propagação de imagem e som; meios reprodutores da linguagem verbal escrita, como a prensa mecânica e outros aparatos tecnológicos, que de certa forma afetam a própria linguagem e a construção de sentidos.

No terceiro, as produções derivadas de matrizes numéricas, geradas por computadores e vídeos. Processos infográficos de produção de linguagens verbais, visuais e sonoras. Virtualidade e simulação.

Com base nessa divisão, a correspondência seria: as narrativas primordiais derivadas das manifestações orais, no primeiro vetor; as formas híbridas de literatura no segundo e as recentes produções infográficas no terceiro.

Tomamos para uma breve abordagem analítica um conto muito conhecido - Chapeuzinho Vermelho - que comparece em diferentes processos de produção de linguagens, projetando interpretantes que engendram essa obra canônica de literatura infantil em plena semiose histórica.

\section{Pelo fio artesanal da produção humana...}

É pouco provável que conheçamos a forma como A menina e o lobo, um conto anônimo, era narrado durante as noites de inverno em torno de lareiras em cabanas de camponeses. Em uma época em que não era necessário um código secreto para falar sobre tabus, decorre a naturalidade com que traz o ato de canibalismo e menciona a dimensão do sexo, da violência e da morte. Esse conto tornou-se muito conhecido com a versão de Charles Perrault (o primeiro a mencionar o capuz vermelho), que traz para o mundo das letras contos da tradição oral, rompendo com fronteiras rígidas entre o popular e o erudito. Chapeuzinho vermelho, como se sabe, recebe ainda um tratamento romântico pela atenção dos irmãos Grimm.

Apesar de ser uma estória sobejamente conhecida, a impossibilidade de escutá-la, nos moldes com que era contada pelos antigos narradores de estórias, é real, posto que, as versões escritas não conseguem transmitir efeitos conseguidos por comunidades não letradas, sem noção de linha, versos, pontuação, procedimentos disponíveis para leitores de páginas impressas. Como provi- 
denciariam as pausas dramáticas, as miradas maliciosas, os gestos para criar cenas. ${ }^{5}$ E, por seu turno, como seriam os silêncios, gritos de aprovação, os cacoetes, olhares de reprovação dos ouvintes, que dispositivos fariam esse texto viver por séculos antes de plasmar-se inerte entre as capas de um livro?

Atualmente, performances de contadores de história, se não nos levam às façanhas dos antigos contadores, levam-nos a depreender como no suporte humano é fantástico o recurso ao aparelho fonador, instrumento musical: pulmões, traquéia, laringe, cordas vocais e, na boca, a língua, palato, região alveolar, dentes, lábios. Enfim, ar, vibração, fricção, nasalidade, possibilidades de contínuo e descontínuo, que fazem da fala linguagem articulada em movimentos sonoros do sopro, murmúrio, grito, palavra - a possível transmutação da fala no encantamento. Dimensão musical de nossa linguagem que ficou esquecida no desenvolvimento da função comunicativa dos idiomas, cujo vinculo é possível reatar quando na concreção material há a subelevação da sensibilidade.

Vislumbramos uma face da linguagem que nasceu do canto e quando deixou de ser cantada, encarnou-se na escritura, buscando sempre a propriedade musical da fala para reencarná-la. Nesse transplante de suportes, aprendemos que a linguagem em algumas manifestações é feita, sobretudo, para ser ouvida e, que nós, sobretudo, somos diagramadores de linguagem.

São diagramas de linguagem que possibilitam, em reescritas intermináveis, uma interação dialética do presente com o passado, renovando-o. São diagramas que, independente do suporte, encarnam e engendram imagens literárias e metáforas, que nos permitem, em tempos outros, dialogar com angústias, anseios, desejos que ao fim e ao cabo, por serem humanos, permanecem.

Os contos populares transmitidos oralmente, como documentos históricos, sugerem mudanças de mentalidade, como afirma Robert Danton, para quem, há subjacente ao fantástico um substrato de realismo social. Essas narrativas revelam formas de o homem relacionar-se com a natureza, representações de mundo que constrói, esquemas nocionais bastante diversos dos que possuímos; desvendam em sua tessitura relações humanas muito complexas

\footnotetext{
5 Sabemos que a invenção da escrita com sua sofisticada maquinaria de combinatória alfabética traz questões muito mais amplas, assunto que não discutiremos aqui, basta lembrar com Pierre Lévy (1996) que: "os modos de conhecimento teóricos e hermenêuticos passaram a prevalecer, impondo-se "uma ecologia cognitiva largamente estruturada pela escrita (num suporte fixo)".
} 
que se modificam social e historicamente. Sendo assim, contextualizar, como ensina Bosi, não é simplesmente datar, é inserir imagens e pensamentos em uma trama, já em si mesma multidirecional, em que se inscrevem valores, experiências de anseios de mudança, suspensão, deslocamento de crenças e esperanças e procurar decifrar essa linguagem que combina arranjos sonoros, visuais e verbais com processos de significação pelos quais sentimento e razão se imbricam em denso tempo histórico (BOSI, 1977: 9).

Entre livros e telas

Com a Revolução Industrial, em decorrência das múltiplas transformações provocadas na vida humana, a forma de perceber e pensar o mundo foram se alterando como se alteraram, também, as relações entre os homens. Para Walter Benjamin (1984: 197-221), em sua atualidade viva, o narrador não está mais presente entre nós, a arte de narrar está em vias de extinção, estamos perdendo a capacidade de intercambiar experiências. Dispersou-se o grupo de ouvintes. Os processos de comunicação passam a ser mediados pela tecnologia. Desenvolvem-se mecanismos de propagação e difusão da voz no espaço e tempo, capazes da reprodução da linguagem verbal escrita, técnicas óticas de formação das imagens, processos híbridos de propagação de imagem e som. Na cultura impressa, narrador e ouvinte inserem-se em simulacro da performance - ambos migram para o objeto livro. Tornam-se artefatos da própria narração.

Fita verde no cabelo: nova velha estória, de Guimarães Rosa, com ilustrações de Roger Mello, é uma versão do conto citado anteriormente no qual a retomada do discurso alheio se dá tanto no verbal quanto no visual, possibilitando reflexões sobre a interação entre duas linguagens e duas culturas.

Fita verde em cada parágrafo se inscreve num jogo de linguagem, impondo aguçada dialética entre realidade e ficção, traz no trajeto a imposição da invenção numa intrincada rede de relações reveladoras da profundidade da escritura roseana, Guimarães, ele próprio um inventor da linguagem e de mundos. Fita verde é obra escrita de extrema finura e que intenta um caminho, senão longo, pelo menos louco, e pouco "encurtoso", para nos revelar em diagrama retroativo a visão de mundo e a consciência de linguagem de que dispõe o escritor Guimarães Rosa.

A narrativa roseana modula a morte da avó não pela ação realizada pelo lobo, mas pela concretude de um ciclo biológico da vida que culmina com a morte. Fita verde é inventada no cabelo. 
Tão inventado quanto fita verde no cabelo da personagem, há o "moinho" como uma referência sugestiva, visto que o narrador o menciona, no texto, durante uma pequena digressão, a respeito do modo de ver humano: "depois daquele moinho, que a gente pensa que vê, e das horas que a gente não vê que não são". Um moinho imaginário, por sua vez, remete-nos à visão quixotesca do mundo. Mas o ilusório estende-se do "moinho" às "horas que a gente não vê que não são", numa menção à passagem do tempo, de modo enganoso.

O tempo aludido é o tempo das criaturas humanas, uma vez que é visto pelos olhos humanos, ainda que de modo ilusório. Seus limites, por conseguinte, são o nascimento e a morte. O tema mais geral. Vida e morte. Conhecido e desconhecido. Juízo e ausência de juízo.

A aventura humana se dá no tempo humano. Fita-Verde inventa, opondose aos que têm juízo. Quando pressentiu a morte da avó, "mais se assustou, como se fosse ter juízo pela primeira vez". Ficar muito assustada estaria ligado ganhar juízo. Mas a expressão "como se" equivale à dinamicidade da recorrência de significantes que não circunscrevem significados específicos, portanto, não concluído. Logo, Fita-Verde, diferente dos demais da aldeia, sintetiza o caráter de sua constituição: é como se fosse adquirir juízo, apenas... como se fosse.

A fita verde no cabelo, inventada, presente na caminhada pelo bosque, é perdida quando chega à casa da avó. A "realidade" da doença, da finitude, finca-se diante da "invenção" ao longo do trajeto "louco". Uma realidade que se impõe diante do inexorável do final do ciclo de vida: "Mas a avó não estava mais lá, sendo que demasiado ausente, a não ser pelo frio, triste e tão repentino corpo". Fase que corrompe a animização da natureza e da vida (inventada) pela súbita "materialização" que marca o destino humano: vai-se a avó (com voz, sentimentos e desejos) e fica um "repentino corpo", "frio, triste e tão repentino corpo", matéria inerte. Nesse intrincado jogo, aguçada dialética. O juízo, o ciclo de vida - nascer, crescer, esperar, velhar - o caminho curto - fazem parte de uma "realidade" - das pessoas da aldeia. Fita-Verde representa uma "outra": nessa não há juízo, a espera passiva é modificada pela tentativa de invenção, o caminho é "louco" e "longo".

No entanto, há a perspectiva do narrador, responsável pelas digressões que nos apontam um frio diagnóstico: "do moinho que a gente pensa que vê" e "das horas que a gente não vê que não são". A ilusão de ver um moinho e a 
percepção enganosa do tempo correspondem a que realidade? Dos moradores da aldeia? De Fita-Verde?

As invenções da personagem, concentradas no quarto parágrafo, são suficientemente fortes para nos levar a algo mais que um embate entre vida e morte. Há no texto uma tentativa de superação da "realidade" que se impõe aos homens. Dito de outra forma, "realidade", de um lado, opondo-se à "invenção", na tentativa de criar outra realidade. Talvez tenhamos aí uma explicação da escolha do subtítulo: "nova velha história". Como que a repetir esse "destino" a que somos conduzidos. Não é por acaso que a avó pressente a finitude; a conversa com a neta está recheada desse pavor. $\mathrm{O}$ tema que subjaz a essa intrincada rede de relações é o da implacabilidade da "materialização" da vida - com a redutibilidade ao "repentino corpo" pela morte, quer se trate dos que têm juízo, quer se trate dos que a inventam ao invés de apenas esperar.

Aos que esperam, o narrador parece atribuir certa "cegueira" - "e das horas que a gente não vê que não são" (as horas que "não são" dizem respeito à ausência de sentido de um tempo simplesmente passando, na sua "materialidade"). Aos que "inventam", recai a irônica constatação de que apenas pensamos ver moinhos (criando conjeturas que não ultrapassam o seu limite), talvez numa versão "quixotesca" e ilusória. E, tanto o "lobo" (sem inicial maiúscula) quanto o "Lobo" (com a inicial maiúscula), tornam-se signo ("desconhecido") e símbolo (de cujo significado apenas nos aproximamos), dessa "realidade" outra.

As narrativas mais antigas expressavam problemáticas humanas fundamentais ligadas ao sensorial, ao visceral, ao estômago e ao sexo, à morte, problemáticas existenciais ligadas aos ritos iniciatórios, ritos de passagem, a relações sociais de poder e sobrevivência, às fronteiriças relações entre natureza e a cultura, além de dimensões éticas do ser humano.

A "nova velha história" de Guimarães Rosa assume um feitio mais metafísico, com interrogações ou afirmações sobre o destino humano. Não há vestígios da dimensão fisiológica, de emoção orgânica, o conto é tecido em outras bases psicossociais.

Ainda neste vetor, comentaremos A última chapeuzinho, um conto musical, curta metragem de Jan Kounem, La dernier chaperon rouge. $\mathrm{Na}$ versão fílmica, são outros os recursos para os quais podemos atentar e que concorrem para a construção de sentidos. Só para citar alguns, roteiro, produção, pós-produção, 
montagem, decupagem, luz, movimentos de câmera, cor, fotografia, qualidade da projeção, da sala de exibição, entre outros. Evidentemente, há muitos elementos a serem analisados, desde a vinheta de apresentação ao fade out do final da película. Os encaixes de seqüências narrativas, descritivas e dissertativas que norteiam ou desnorteiam o enredo.

De forma breve, nos limitaremos a alguns pontos interessantes que consubstanciam essa versão cinematográfica da estória, que traz a violência, e o erotismo da primeira versão, assim como a morte. Todos esses elementos em outras claves de ressonância.

É interessante apontar como o verbal é totalmente subvertido pela visualidade, a estória se tece com fios multifacetados, reconhecem-se pontos de apoio, mas são apenas flashes, índices intertextuais que tramam internarrativas. A mídia corrói a lógica com seqüências intermitentes, instaurando a descontinuidade. A própria mídia em fade out corrói a cena. Percebe-se como o roteiro cria dissociações em rompimento à linearidade. Podemos observar a lógica de uma linguagem engendrando-se em outra, na construção de sentidos, observamos diagramas narrativos que se constroem em verticalidade, a narrativa cuja característica basilar é ser temporal, verticaliza-se, espacializa-se, temos microssequências em seqüências maiores que engendram um encadeamento interno (entre menor e maior) e externo (entre as maiores) estamos diante de configurações de narrativas que são e que aspiram ser - são potenciais. A própria linguagem potencializa o conflito.

Presentes o grotesco, a devoração antropofágica, a polifonia e o encaixe de narrativas em simultaneidade, a relação com a modernidade e a estética da complexidade estabelece-se. Desconcertado, o receptor, ao parar o fio, faz com que de alguma forma renasça. A metáfora do ler se faz presente no jogo das linguagens - ler como devorar; como elemento simbólico, a floresta é domínio do mistério, há algo hipnótico que desvia do caminho - sedução; o jogo de olhares, quem vejo me vê - a ilusão especular de contrato discursivo; a presença necessária de um grande devorador - o lobo? - ou você leitor. Devoração, que perpetua o objeto devorado em seu ser, processo de assimilação sígnica que simbolicamente encapsula o objeto e o faz renascer em traduções renovadas. A morte, a canibalização, o erotismo estão presentes.

Não há vestígios da dimensão fisiológica, de emoção orgânica, as inúmeras mediações simbólicas que presidem a elaboração desta película são atos de 
linguagem, são técnicas de produção de sentido. Verifica-se o filme como objeto artístico, configurando-se no engendrar de sensorialidade, percepção, representação e estilização. Produto de imaginação construtiva, de conhecimento de estruturas, envolvendo historicidade e reflexão crítica. Deixa entrever, no complexo estético da linguagem cinematográfica, a consciência de linguagem própria de nosso tempo, e de nossa sociedade mediada pelas técnicas de produção de linguagem.

\section{Pelas malhas virtuais - A interminável chapeuzinho $-{ }^{6}$}

O conhecido conto, em linguagem da hipermídia, encontra-se agora disponível a navegações do ciberespaço; as personagens são figuras sintéticas com animação. As ações das personagens dependem do cursor do mouse e do diagrama interno ao programa de computação. Assim, a dinâmica da narrativa é dada por dois movimentos: um interno e outro externo, na interação do receptor com a tela por meio de um programa do computador.

É pela concorrência do som e do silêncio que se tem a impressão de que há uma completude no movimento. O enredo é construído visual e sonoramente, o encadeamento vai se dando na medida em que se movimenta o mouse. Desse modo, a narrativa monta-se com a intervenção de seu receptor munido de um instrumento de comando. É importante o papel da linguagem sonora para marcar a sintaxe e a temporalidade narrativa.

O receptor é colocado no jogo e pelo apagamento das marcas referenciais não detecta se a natureza sonora é real ou sintetizada. As figuras que representam personagens ora são ícones de navegação, ora agem por si próprias; no espaço ou cenário, há sinalizações que funcionam também como orientadores de desafios que o internauta enfrenta ante a tomada de decisão ao clicar o mouse. As imagens funcionam como índices e vão requerer do leitor o acionar de sua memória textual para a navegação, por alguns caminhos. Isso permite o desenrolar da narratividade na mesma medida em que esta requer a leitura dos elementos representativos das figuras da menina, do animal, das mulheres, do aparecimento (ou não) dos caçadores. Dessa forma, faz-se necessário o processar

6 Angela Lago (www. angela-lago.com.br). 
de reflexões e relações para compreensão dos sentidos que se constroem com a estrutura circular e o recurso da metalinguagem. O som manifesto atesta, em suas inflexões, o caráter de linguagem híbrida. Nesse clima de mensagens cifradas, o leitor se vê diante de possibilidades narrativas, diante de um jogo, em que escolhe, entre alternativas, a história que prefere atualizar.

Ao fim e ao cabo, estamos diante do nascimento de uma produção derivada de matrizes numéricas, gerada por computadores e vídeos, estamos diante de processos infográficos de produção de linguagens verbais, visuais e sonoras. Virtualidade e simulação. A matéria narrável - entre o dito e o não dito - assume formas multi-luz-cor, texturas, sombras e luzes que orquestram sentidos. A palavra, texto, imagens fixas e animadas intercambiam funções na trama de um tecido comum; sons, vozes, música, ruídos são importados de outros suportes e orquestram, agora, em arquiteturas líquidas.

O receptor imerge nesse ambiente em processos de busca, interagindo com os nós e nexos de um roteiro multilinear e labiríntico, que ele ajuda interativamente a construir, como usuário também escolhe um percurso, entre muitas possibilidades, e estabelece sua co-participação na produção das mensagens. Desse modo, ambientes multimidiáticos promovem o acesso a espaços comuns entre produção e recepção, providenciam mecanismos de interação e de manipulação.

Em um ambiente muito lúdico, a violência e a morte aparecem de forma muito sutil. Em metalinguagem, retorna-se ao livro para conferir o desenvolvimento da estória. A interminável chapeuzinho se constrói de múltiplas formas na conjunção dos movimentos, de quadros visuais e da canção que a menina cantarola, "La vie em rose", canção, na qual o eu lírico é uma mulher apaixonada pelo amante. Como recurso de montagem conceitual, permite entrever a inscrição do erotismo, do despertar da sexualidade feminina, da paixão e do desejo, em caminhos de exploração e descoberta. Há uma forte alusão ao papel de emancipação do feminino.

Um diagrama subjaz às possibilidades de navegação que o texto permite. Nele é possível perceber uma estrutura arborescente. Os vários caminhos fornecem ao leitor atos de leitura e de conferência, e remetem em metalinguagem a percursos de leitura, como ato complexo que aciona estratégias cognitivas e metacognitivas, engendrando hipóteses, experimentações, conferência, controle, e que permite amadurecimento. 
O conto apropriado e reapropriado de acordo com a maneira de cada tempo histórico, de cada cultura e sociedade desvela sua estrutura mítica, não como registro apenas de histórias arquetípicas do passado, mas como materialização de impulsos em forma de narrativa, revelando historicidade e formações complexas do psiquismo humano, de diferentes consciências de linguagem, de atos comunicativos em diferentes épocas e diferentes contextos sociais e culturais. Ao movimentar-se no tempo histórico, a produção literária deixa entrever elementos de sua gênese nas absorções, nos diálogos e transformações. A recepção dinamiza e modifica de forma constante a leitura desses processos.

\section{Considerações finais}

Sugerimos no início deste texto que a literatura seria uma forma de fazer avançar o projeto humano do homem. Isto vale também e em especial para a Literatura, um dia denominada infantil, e que não envelhece, que projeta seus raios de ação para fora da história. Dito de outro modo, Literatura para adultos, para jovens e para crianças, sem qualquer adjetivação. Literatura, que ao deparar-se com a força indômita da linguagem, cifra - e porque cifra, inexoravelmente, em cada obra, faz comparecer todas - vertigem do Aleph.

Diante dos desafios desta nossa era, sob a luz da teoria, buscam-se paradigmas que abrandem a vertigem. Daí, a nossa procura: estudos que o façam, mas que também se retroalimentem por obras capazes de sacudir a teoria da inércia. Pensando desse modo é que num olhar de sobrevôo, aqui, neste texto fizemos comparecer alguns ensinamentos que estão fornecendo compreensão sobre campos de investigação que nos desafiam e que merecem portos seguros de ancoragem.

\section{Referências Bibliográficas}

ABDALA JÚNIOR, Benjamin. Fronteiras múltiplas, identidades plurais. São Paulo: Senac, 2002.

BENJAMIN, Walter. Magia e técnica, arte e política. São Paulo: Brasiliense, 1984. 
BOSI, Alfredo. O ser e o tempo na poesia. São Paulo: Companhia das Letras, 1977. Reflexões sobre a arte. São Paulo: Ática, 2004.

CANDIDO, Antonio. Literatura e sociedade. 7. ed. São Paulo: Ed. Nacional, 1985.

CHARTIER, Roger. A aventura do livro: do leitor ao navegador. São Paulo: Ed. Unesp; Imprensa Oficial do Estado de São Paulo, 1999.

CUNHA, Maria Zilda. A literatura infantil e os novos meios de produção de linguagem. In: Pedagogias do imaginário: olhares sobre a literatura infantil. Lisboa: ASA, 2002.

Matrizes de linguagem e pensamento na literatura infantil e juvenil: a tessitura dos signos em obras de Angela Lago e Otaviano Correa. São Paulo, 2002. Tese (Doutorado). Universidade de São Paulo.

FLÜSSER, V. Filosofia da caixa preta. São Paulo: Hucitec, 1985.

MORIN, Edgar. A religação dos saberes: o desafio do século XXI. 3. ed. Rio de Janeiro: Bertrand Brasil, 2002.

PLAZA, Julio; TAVARES, Monica. Processos criativos com os meios eletrônicos: poéticas digitais. São Paulo: Hucitec, 1998.

SANTAELLA, Lucia. Navegar no ciberespaço: o perfil cognitivo do leitor imersivo. São Paulo: Paulus, 2007. . Cultura das mídias. Ed. rev. e ampl. São Paulo: Experimento, 1996. . Matrizes da linguagem e pensamento: sonora, visual e verbal. São Paulo: Iluminuras, 2001. 